\title{
HUBUNGAN KEPERCAYAAN DIRI DENGAN TINGKAT KECEMASAN PADA MAHASISWA KELAS ALIH TRANSFER PROGRAM SARJANA KEPERAWATAN
}

\author{
Haidir Syafrullah ${ }^{1}$, Cucu Rokayah ${ }^{1}$, Resti Nurdini ${ }^{1}$ \\ ${ }^{1}$ Program Studi Sarjana Keperawatan, Sekolah Tinggi Ilmu Kesehatan Dharma Husada Bandung \\ cucurokayah611@gmail.com
}

\begin{abstract}
ABSTRAK
Kepercayaan diri adalah suatu sikap, perasaan yakin atas kemampuan diri sendiri. Mahasiswa dengan kepercayaan diri positif memiliki kemampuan untuk mencapai tujuan dalam hidup, tidak akan mudah menyerah dan mudah mengalami kecemasan dalam menghadapi kesulitan pada saat menyusun skripsi. Penelitian bertujuan untuk mengetahui hubungan antara kepercayaan diri dengan tingkat kecemasan.Metode penelitian bersifat deskriptif korelasi dengan pendekatan cross-sectional. Populasi penelitian sebanyak 70 sampel dengan metodetotal sampling. Instrumen penelitian berupa kuisioner kepercayaan diri Lauster dan kuesioner DASS (Depression Anxiety Stress Scale). Hasil penelitian menunjukkan tingkat kepercayaan diri positif 35 orang $(50 \%)$ dan tingkat kecemasan berat 9 orang $(12,86 \%)$ serta terdapat hubungan yang signifikan antara kepercayaan diri dengan tingkat kecemasan ( $p$-value $=0,009)$, mahasiswa kelas alih tranfer tingkat akhir program studi sarjana keperawatan di STIKes Dharma Husada Bandung. Saran untuk institusi pendidikan melalui pembimbing akademik dapat memberikan lebih banyak motivasi dan sugesti positif terhadap mahasiswa yang tengah menyusun skripsi dan diadakan bimbingan dan konseling kepada mahasiswa.
\end{abstract}

Kata Kunci: Kepercayaan Diri, Tingkat Kecemasan

\section{THE RELATIONSHIP BETWEEN SELF-CONFIDENCE AND ANXIETY LEVEL ON THE STUDENT OF LAST GRADE BACHELOR PROGRAMME IN NURSING WHO WERE IN THE TRANSFERRED-CLASS AT DHARMA HUSADA BANDUNG INSTITUTE OF HEALTH SCIENCE}

\begin{abstract}
Self-confidence is a certain attitude or feeling of self-assurance. Students with positive self-confidence have the ability to achieve goals in their life. They would not give up nor easily experience anxiety, when facing difficulties at the time of preparing their thesis. The study aimed to determine the relationship between selfconfidence and the level of anxiety. The research method was descriptive correlation with cross-sectional approach. The research population was 70 samples and total sampling method was used. The research instruments were Lauster self-confidence questionnaire and anxiety level questionnaire with DASS (Depression Anxiety Stress Scale) measurement scale. The results showed that 35 people (35\%) positive selfconfidence leveland $12.86 \%$ with very heavy anxiety level and significant correlation between selfconfidence and the level of anxiety ( $p$-value $=0.009)$ on the students of Dharma Husada Bandung Institute of Health Science who were in the transferred-class at their final semester. The research suggested the educational institutions, through the supervisors, to provide more positive motivations and suggestions for the students who were in their thesis preparation and to held counseling for the students with very heavy anxiety level.
\end{abstract}

Keywords: Anxiety Level, Self Confidence

\section{PENDAHULUAN}

Perguruan Tinggi adalah satuan pendidikan yang menyelenggarakan pendidikan tinggi.Bagi pendidikan program sarjana wajib ditambah bentuk pembelajaran berupa penelitian, perancangan atau pengembangan dengan pemintatan tertentu.Penelitian yang dilakukan pada program sarjana disebut juga dengan skripsi.Skripsi adalah karya ilmiah yang ditulis mahasiswa program S1 yang membahas topik atau bidang tertentu berdasarkan hasil kajian pustaka yang ditulis oleh para ahli, hasil penelitian lapangan, atau hasil pengembangan (eksperimen).

Mahasiswa sering kali menghadapi berbagai kendala dalam menyusun skripsi baik dari dalam diri sendiri maupun dari luar. Berbagai kendala atau kesulitan yang dihadapi mahasiswa dalam menyusun skripsi akan berdampak pada 
penundaan skripsi dan mahasiswa dilanda kecemasanan jika tidak mampu menyelesaikan skripsi tepat waktu, (Kristanto H, P. Sumardjono, dan Setyorini 2014). Menurut Hidayat (2010). Kesulitan-kesulitan saat penyusunan skripsi oleh mahasiswa sering dirasakan sebagai suatu beban yang berat, akibatnya kesulitan-kesulitan yang dirasakan tersebut berkembang menjadi sikap yang negatif yang akhirnya dapat menimbulkan suatu kecemasanan.

Menurut Stuart (2013) kecemasan adalah rasa takut yang tidak jelas disertai ketidakpastian, ketidakberdayaan, isolasi dan ketidaknyamanan. Kecemasanan memiliki dua aspek yakni aspek sehat dan aspek membahayakan tergantung pada tingkat kecemasan, lama kecemasan yang dialami dan seberapa baik individu melakukan koping terhadap kecemasan (Videbeck, 2008). Kecemasanan pada tahap tertentu akan berakibat buruk bagi kesehatan.

Ada empat tingkat kecemasan menurut Peplau (1963) dalam Stuart (2013).Tanda-tanda pada kecemasan ringan seseorang menjadi waspada dan lapang persepsi meningkat dan dapat memotivasi belajar dan menghasilkan kreatifitas sehingga seseorang dengan kecemasan ringan memungkinkan mahasiswa mampu menyelesaikan skripsinya. Kecemasan sedang seseorang hanya berfokus pada hal yang penting saja dan lapang persepsi menyempit sehingga kurang melihat, mendengar dan menangkap, sedangkan pada kecemasan berat ditandai dengan penurunan yang signifikan pada lapang persepsi, seseorang dengan kecemasan berat cenderung memfokuskan pada hal detail dan tidak berfikir tentang hal lain dan pada kecemasanan sangat berat atau panik individu mengalami peningkatan aktivitas motorik, penurunan kemampuan untuk berhubungan dengan orang lain, lapang persepsi semakin menyempit sehingga tidak dapat melakukan sesuatu, tidak mungkin untuk belajar.

Kecemasanan yang tidak sehat akan
mempengaruhi fungsi kognitif sehingga
menghasilkan masalah pada konsentrasi,
kebingungan dan pemecahan masalah yang buruk
yang dapat menjadikan hambatan dalam
penyusunan skripsi (Stuart, 2013). Kecemasan
dalam mengerjakan skripsi dibutuhkan
kepercayaan diri, karena dengan kepercayaaa diri
yang tinggi merupakan salah satu faktor internal
dalam diri individu ketika penyelesaian
pengerjaan skripsi. Kepercayaan diri merupakan
keyakinan atas kemampuan diri sendiri sehingga
dalam tindakannya mahasiswa tidak terlalu

merasakan kecemasan, merasa bebas untuk melakukan hal-hal yang sesuai dengan keinginan, bertanggung jawab atas perbuatannya, sopan dalam berinteraksi dengan orang lain, memiliki dorongan berprestasi sekaligus mengenal kelebihan dan kekurangan diri sendiri (Lauster, 2003).

Kepercayaan diri sangat mempengaruhi pada ketahanan diri seseorang dalam menghadapi berbagai hambatan (Suhron, 2017). Mahasiswa dengan kepercayaan diri yang positif akan berusaha mendapatkan jalan keluar untuk mengatasi berbagai hambatan yang dapat mengganggu penyelesaian skripsinya. Anthony dalam Ghufron dan Risnawita (2010) menyebutkan bahwa percaya diri merupakan sikap pada diri seseorang yang dapat menerima kenyataan, dapat menggembangkan kesadaran diri, berpikir positif, memiliki kemandirian, dan mempunyai kemampuan untuk memiliki serta mencapai segala sesuatu yang diinginkan. Salah satu aspek kepercayaan diri berupa keyakinan untuk mampu mencapai hasil yang diharapkan.

Keyakinan yang dimiliki mahasiswa akan semakin mempengaruhi tingkat kepercayaan diri seorang mahasiswa dalam menyelesaikan skripsi tepat waktu. Mahasiswa yang mempunyai kepercayaan diri yang baik memiliki kemampuan untuk mencapai tujuan dalam hidup, tidak akan mudah menyerah dan tidak akan mudah mengalami kecemasanan dalam menghadapi kesulitan pada saat penyusunan skripsi. Skripsi yang tidak dapat diselesaikan tepat pada waktu akan menimbulkan kecemasanan pada mahasiswa, apabila hal tersebuttidak diatasi akan muncul pikiran-pikiran negatif yang membahayakan. Penelitian ini bertujuan untuk mengetahui apakah ada Hubungan antara Kepercayaan Diri dengan tingkat kecemasan pada mahasiswa kelas alih transfer tingkat akhir program studi Sarjana Keperawatan.

\section{METODE}

Penelitian ini menggunakan pendekatan kuantitatif dengan desain deskriptif korelasi.Variabel bebas dalam penelitian ini adalah kepercayaan diri dan variabel terikat penelitian ini adalah tingkat kecemasan.Penelitian ini dilakukan pada 70 mahasiswa STIKes Dharma Husada Bandung. Teknik sampling yang digunakan total sampling dengan pendekatan waktu cross sectional. Alat pengumpul data kepercayaan diri berupa kuesioner yang dikembangkan berdasarkan aspek-aspek kepercayaan diri Lauster sebanyak 32 pernyataan 
sedangkan instrumen tingkat kecemasan berupa kuesioner yang dikenal dengan skala pengukuran DASS (Depression Anxiety Stress Scale) yang dipelopori oleh Lovibond (1995) sebanyak 14 pertanyaan. Analisis data dilakukan dengan ChiSquare menggunakan program komputer. Peneliti meminta responden untuk menandatangani informed consent sebelum melakukan penelitian.

\section{HASIL}

Hasil penelitian dapat dilihat pada tabel berikut.

Tabel 1.

Gambaran tingkat kepercayaan diri mahasiswa kelas alih transfer tingkat akhir program studi sarjana keperawatan $(\mathrm{n}=70)$

\begin{tabular}{|c|c|c|}
\hline Kepercayaan Diri & $f$ & $\%$ \\
\hline Positif & 35 & 50 \\
\hline Negatif & 35 & 50 \\
\hline
\end{tabular}

Tabel 2.

Gambaran tingkat kecemasan mahasiswa kelas alih transfer tingkat akhir program studi sarjana keperawatan

\begin{tabular}{lcc} 
& $(\mathrm{n}=70)$ & \\
\hline Kekecemasanan & $\mathrm{f}$ & $\%$ \\
\hline Normal & 21 & 30,00 \\
Kecemasan Ringan & 6 & 8,57 \\
Kecemasan Sedang & 17 & 24,29 \\
Kecemasan Berat & 17 & 24,29 \\
Kecemasan Sangat Berat/Panik & 9 & 12,86 \\
\hline
\end{tabular}

Tabel 3.

Hubungan antara kepercayaan diri dengan tingkat kecemasan pada mahasiswa kelas alih transfer tingkat akhir $\mathrm{n}=70$ )

\begin{tabular}{ccccccccc}
\hline Kepercayaan diri & \multicolumn{9}{c}{ Kecemasan } & Total & P value \\
\cline { 2 - 7 } & & Normal & Ringan & Sedang & Berat & Panik & & \\
\hline Positif & f & 16 & 4 & 6 & 8 & 1 & 35 & \\
& $\%$ & 22.86 & 5.71 & 8.57 & 11.43 & 1.43 & 50 & $0,009^{*}$ \\
\hline Negatif & $\mathrm{f}$ & 5 & 2 & 11 & 9 & 8 & 35 & \\
& $\%$ & 7.14 & 2.86 & 15.71 & 12.86 & 11.43 & 50 & \\
\hline
\end{tabular}

\section{PEMBAHASAN}

Hasil uji statistik didapatkan hasil bahwa dari 70 mahasiswa kelas alih transfer tingkat akhir program studi sarjana keperawatan di Stikes Dharma Husada Bandung yang sedang menghadapi skripsi, 35 orang $(50 \%)$ memiliki kepercayaan diri positif. Kepercayaan diri yang dimiliki seseorang dipengaruhi banyak faktor baik internal maupun eksternal.Seperti dikemukakan Suhron (2017) yang menyebutkan bahwa kepercayaan diri dipengaruhi konsep diri pada seseorang atau penilaian terhadap dirinya juga pengalaman hidup yang telah dimilikinya sehingga seseorang bisa memiliki kepercayaan diri positif ataupun negatif.

Kepercayaan diri adalah suatu sikap atau perasaan yakin atas kemampuan diri sendiri (Suhron, 2017). Kepercayaan diri positif yang dimiliki mahasiswa kelas alih transfer program studi sarjana keperawatan STIKes Dharma Husada pada aspek kemampuan dirinya berupa pikiran terhadap dirinya yang normal dan cakap akan kemampuan dirinya, tidak pernah berpikir negatif terhadap diri sendiri juga melakukan pekerjaan tanpa mengharapkan perhatian dan pujian dari orang lain. Aspek interaksi sosial yang dimiliki mahasiswa berupa tidak merasa takut berbicara dengan orang yang baru, merasa aman dalam lingkungan saat ini dan tidak merasa khawatir terhadap sesuatu yang belum terjadi.Semua hal tersebut merupakan modal dalam diri mahasiswa untuk dapat menyelesaikan skripsinya.

Seseorang yang memiliki kemampuan mengatasi setiap asumsi atau persepsi negatif yang muncul dalam diri sendiri (positif thingking) dan selalu menggunakan self-affirmation atau penegasan dalam diri sendiri yang berupa kata-kata positif akan memiliki kepercayaan diri yang positif. Motivasi dan niat yang kuat juga berpengaruh terhadap kepercayaan diri (Fatimah, 2008). 
Berdasarkan tabel 2 dapat diketahui gambaran kecemasan dari 70 mahasiswa diadapatkan sebanyak 21 orang (30\%) merupakan mahasiswa yang tidak memiliki kecemasan dan 43 orang memiliki tingkat kecemasan sedang dan kecemasan berat. Kecemasan mahasiswa merupakan bagian yang tidak terpisahkan dari pendidikan.Setiap mahasiswa merasakan sejumlah kecemasan pada suatu waktu saat perkuliahan, untuk mahasiswa tertentu kecemasan menghambat belajar serta kinerja mereka secara serius khususnya pada saat penyusunan skripsi.Banyak mahasiswa yang gelisah bila menghadapi skripsi karena merupakan tugas akhir yang menentukan kelulusan dalam perkuliahan.Beberapa mahasiswa merasakan skripsi merupakan beban yang berat.

Berbagai respon yang dialami mahasiswa kelas alih transfer tingkat akhir program studi sarjana keperawatan terhadap kecemasan di antaranya sebagian besar mahasiswa kadang-kadang merasakan mulut kering dan merasa takut terhambat oleh tugas-tugas yang tidak biasa dilakukan seperti menyelesaikan tugas skripsi yang mendekati batas waktu penyelesaiannya. Mahasiswa yang lainya sering merasa khawatir dengan situasi saat itu dan takut mempermalukan diri sendiri, sebagian besar mahasiswa juga sering merasakan kecemasan berlebih dalam situasi tertentu dan baru dapat merasa lega kembali setelah situasi tersebut berakhir. Tanda dan gejala tersebut sering bahkan selalu dirasakan oleh mahasiswa dengan tingkat kecemasan sangat berat dan menimbulkan kelelahan pada mahasiswa tersebut.Kecemasan berat dan sangat berat apabila terus berlangsung tidak menutup kemungkinan perlunya bimbingan konseling terhadap mahasiswa tersebut.

Sisi negatif dari kecemasan adalah rasa khawatir yang berlebihan tentang masalah yang nyata atau potensial dan menghabiskan tenaga, menimbulkan rasa takut, menghambat individu melakukan fungsinya dengan adekuat dalam situasi interpersonal, situasi kerja dan situasi sosial (Videbeck, 2008). Banyaknya mahasiswa dengan tingkat kecemasan sedang dan berat akan menghambat proses penyusunan skripsi, dikarenakan tingkat kecemasan sedang dan berat mempengaruhi lapang persepsi seseorang. Seseorang dengan tingkat kecemasan sedang hanya berfokus pada hal-hal penting saja, lapang persepsi mulai menyempit sehingga kurang melihat, mendengar dan menangkap materi apapun terutama yang berhubungan dengan penyusunan skripsi (Peplau, 1963 dalam Stuart,
2016). Respon kognitif pada tingkat kecemasan sedang menunjukkan penyelesaian terhadap masalah yang menurun dan pembelajaran terjadi dengan lebih banyak memfokuskan terhadap masalah (Videbeck, 2008).

Begitu pula dengan kecemasan berat terjadi penurunan yang signifikan pada lapang persepsi, seseorang cenderung fokus pada hal-hal detail dan tidak berfikir tentang hal yang lain (Peplau, 1963 dalam Stuart, 2013).Respon kognitif yang ditunjukkan menurut Videbeck (2008) berupa penyelesaian masalah yang buruk, tidak mampu mempertimbangkan informasi, hanya memperhatikan ancaman dan preokupasi dengan pikirannya sendiri dan cenderung egosentris.

Hasil uji korelasi dengan teknik Chi-Square menghasilkan bahwa hipotesis diterima yang artinya adalah ada hubungan $(\mathrm{p}=0,009$ dan $\mathrm{p}$ $<0,05)$ antara kepercayaan diri dengan tingkat kecemasan mahasiswa dalam menghadapi skripsi. Penelitian menunjukkan koefisien korelasi yang negatif yang berarti semakin negatif kepercayaan diri mahasiswa dalam menghadapi skripsi maka akan semakin tinggi tingkat kecemasannya. Temuan penelitian ini sejalan dengan hasil penelitian Pratiwi (2008) yang menyatakan bahwa ada hubungan negatif yang sangat signifikan antara kepercayaan diri dengan kecemasan dalam proses bimbingan skripsi pada mahasiswa Psikologi Universitas Muhammadiyah Malang, dengan koefisien korelasi $\mathrm{r}=-0,462$ dan $\mathrm{p}=$ 0,002 .

Mahasiswa kelas alih transfer tingkat akhir program studi sarjana keperawatan STIKes Dharma Husada Bandung memiliki berbagai latar belakang usia, jenis kelamin dan pekerjaan yang berbeda. Hasil penelitian menunjukkan 65 orang (92\%) mahasiswa berada pada usia dewasa awal yaitu rentang usia 18 sampai 40 tahun, pada usia ini tingkat emosional dan sosial seseorang sudah mulai matang, mengetahui dan menerima kemampuan sendiri serta tanggung jawabnya dalam menyelesaikan tugas-tugas hidup. Berdasarkan hal tersebut seharusnya mahasiswa berada pada posisi memiliki kepercayaan diri yang positif dengan tingkat kecemasan yang rendah.

Kecemasan berat dan sangat berat banyak dialami oleh mahasiswa dengan rentang usia 17-25 tahun. Berbagai hal memungkinkan usia ini menjadi lebih banyak mengalami kecemasan berat dan sangat berat dalam menyusun skripsi karena pada usia ini seseorang mulai menyesuaikan diri 
mengambil tanggung jawab terhadap berbagai keputusan yang diambil tanpa melibatkan orang tua. Banyak yang kesulitan menghadapi berbagai masalah yang timbul sehingga menimbulkan kecemasan.

\section{SIMPULAN DAN SARAN}

\section{Simpulan}

a. Kepercayaan diri mahasiswa kelas alih transfer tingkat akhir program studi sarjana keperawatan di STIKes Dharma Husada Bandung dalam menghadapi skripsi terdapat 35 orang $(50 \%)$ memiliki kepercayaan diri positif.

b. Tingkat kecemasan pada mahasiswa kelas alih transfer tingkat akhir program studi sarjana keperawatan di STIKes Dharma Husada Bandung dalam menghadapi skripsi terdapat 17 orang $(24,29 \%)$ dengan tingkat kecemasan sedang dan berat, dan 9 orang $(12,86 \%)$ dengan tingkat kecemasan sangat berat.

c. Tingkat kepercayaan diri memiliki hubungan yang signifikan dengan tingkat kecemasan pada mahasiswa kelas alih transfer tingkat akhir program studi sarjana keperawatan di STIKes Dharma Husada Bandung dengan nilai $p$ value lebih kecil dari nilai $\alpha$ yaitu $0,009<0,05$.

\section{Saran}

Peneliti selanjutnya diharapkan dapat memberikan intervensi dengan menggunakan hasil penelitian ini sebagai acuan penelitian selanjutnya sehingga stres yang dialami mahasiswa dapat berkurang.

\section{DAFTAR PUSTAKA}

Fatimah, E. 2008.Psikologi Perkembangan: Perkembangan Peserta Didik.Bandung : Pustaka Setia.

Hidayat.(2010). Menyusun Skripsi dan Tesis. (Edisi Revisi). Bandung : Informatika

Kristanto H, P. Sumardjono, dan Setyorini, (2014). Hubungan Antara Kepercayaan Diri Dengan Kekecemasanan Dalam Menyusun Proposal Skripsi.FKIP Universitas Kristen Satya Wacana. Satya Widya, Vol.30, No.1, 2014

Lauster, P. (2012). Tes kepribadian.Jakarta : PT. Bumi Aksara.

Suhron, M (2017). Asuhan keperawatan Jiwa Konsep Self Esteem.Jakarta: Mitra Wacana Media

Videbeck, Sheila L . (2008). Buku Ajar Keperawatan Jiwa .Jakarta : EGC 